\title{
Severe injury to the brachial neurovascular bundle and muscles due to a horse bite: a case report
}

Hajriz Rudari, Luan Jaha*', Adhurim Koshi and Lulzim Vokrri

\begin{abstract}
Introduction: Only a small portion of horse injuries are related to horse bites. In the majority of these occurrences, injuries are minor and self-treated. However, in some cases, the injury may be destructive and limb- and life-threatening. In these instances, the patient requires complex surgery and compound perioperative care.

Case report: We present the case of a 35-year-old Albanian male farm-worker in whom a horse bite caused an extensive lacero-contusive and avulsive wound to the arm. The wound resulted in injury to the brachial artery, brachial and basilic vein, and biceps and brachialis muscles. Nerve structures and underlying humerus remained intact. The initial management of the severe hemorrhagic shock caused by the bleeding at the site of injury included reconstruction of the brachial artery by interposing saphenous graft and that of the brachial vein by termino-terminal anastomosis. Basilic vein was ligated. The wound was extensively debrided, and after a drain was placed in the wound, biceps and brachialis muscles were reconstructed. The patient received several units of red blood cells and fresh frozen plasma before and after surgery, as well as antibiotic, antitetanic, and antirabies prophylaxes. He had several consecutive necrectomies in the following days. However, due to postoperative sepsis and hemorrhagic shock at time of admission, the patient developed acute renal failure, therefore requiring several hemodialysis sessions. After his general and local condition was stabilized, the patient also underwent several reconstructive surgeries.

Conclusion: Horse bites of large extent require a multidisciplinary approach. The composition of the team of physicians needed for treatment varies depending on the degree of the injury and eventual complications. In the case of our patient, emergency department physicians, vascular and plastic surgeons, intensive care specialists, nephrologists, and infective care specialists were involved. In different instances, the inclusion of other specialists may be necessary to save and functionalize the limbs of the patient, or save his/her life.
\end{abstract}

Keywords: Horse bite, Arterial injury, Sepsis, Hemodialysis

\section{Introduction}

Animal bites are fairly common. Almost $2 \%$ of all emergency admissions are related to animal bites [1], with dog bites being the most frequent $(80 \%-90 \%)$, followed by cat and human bites. Horse bites account for only a small portion of animal bites [2]. The head and neck are the

*Correspondence: luan.jaha@universitetiaab.com Department of Vascular Surgery, University Clinical Center of Kosova, Pristina, Republic of Kosovo most frequent horse bite sites, followed by the extremities and trunk [3]. Injuries to the great vessels, especially those exsanguinating, are very rare.

In the majority of occurrences, horse bite injuries are minor and self-treated. However, in some cases, the injury may be destructive, and limb- and life-threatening. In these instances, the patient will require complex surgery and compound perioperative care. This was the case with our patient in whom a horse bite caused laceration original author(s) and the source, provide a link to the Creative Commons licence, and indicate if changes were made. The images or other third party material in this article are included in the article's Creative Commons licence, unless indicated otherwise in a credit line to the material. If material is not included in the article's Creative Commons licence and your intended use is not permitted by statutory regulation or exceeds the permitted use, you will need to obtain permission directly from the copyright holder. To view a copy of this licence, visit http://creativecommons.org/licenses/by/4.0/. The Creative Commons Public Domain Dedication waiver (http://creativeco mmons.org/publicdomain/zero/1.0/) applies to the data made available in this article, unless otherwise stated in a credit line to the data. 
of brachial artery and vein that led to hemorrhagic shock, complicated with infection and renal failure.

\section{Case report}

A 35-year-old Albanian male farm-worker without relevant medical, physical, or psychosocial history was brought to our emergency room in a state of major hemorrhagic shock with an injury inflicted by a horse bite, just 5 hours prior to admission. His arm was heavily deformed with skin, fascia, and muscles torn from the humerus, which was visible at the bottom of the wound (Fig. 1a, b). Due to thrombosis of the lacerated vessels, there was no bleeding at time of admission. Pulse was missing on the right radial and ulnar arteries, and movement was limited. It was impossible to correctly examine nerve function due to difficulties in communication caused by the state of shock. We covered the wound and started resuscitation.

The patient was confused and anxious, and his skin was pale, cold, and sweaty. He was breathing rapidly. The pulse on his left radial artery was weak, rapid,
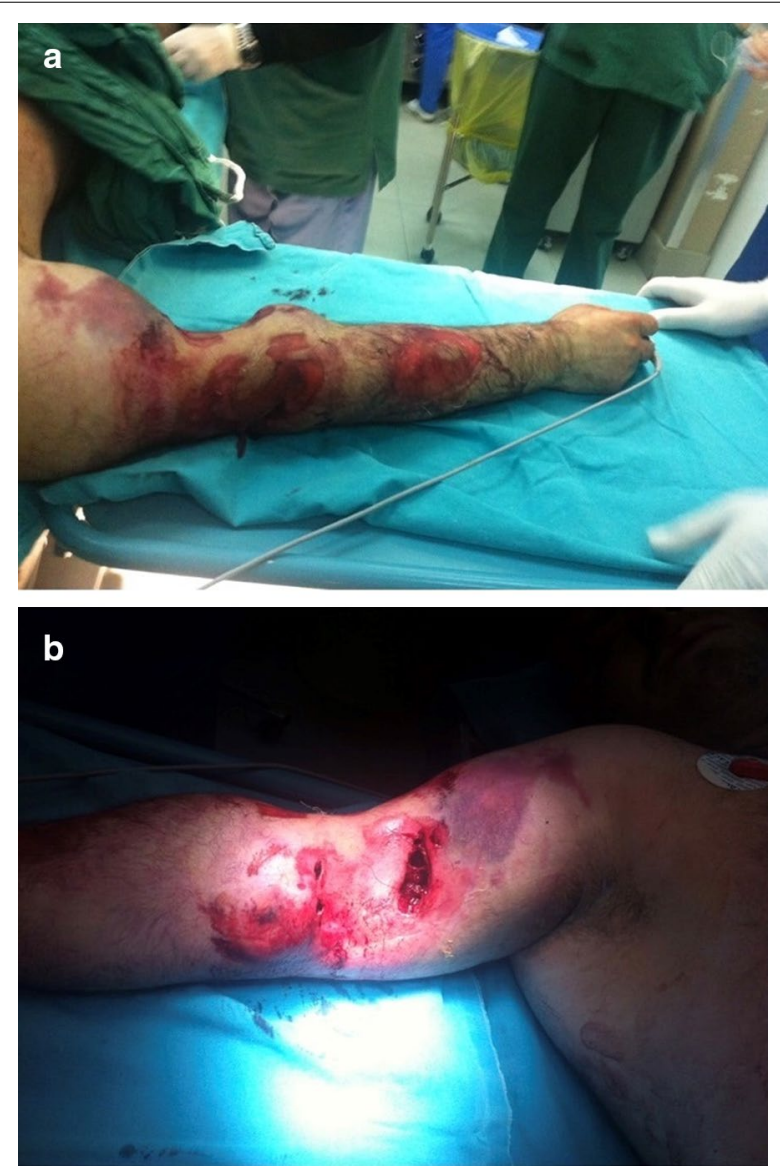

Fig. 1. Horse bite injury of right upper extremity: lateral (a) and medial (b) aspects and thready. Pulse in his right arm was missing. His fingernails and lips were blue, and his capillary refill time was 5 seconds. He had blood pressure of 70/40 $\mathrm{mmHg}$, heart rate of 130 beats/minute, and peripheral capillary oxygen saturation of $92 \%$. His hematocrit was $18 \%$, and his hemoglobin was $6.8 \mathrm{~g} / \mathrm{dL}$. His platelet count was normal, and his white blood cell count was slightly elevated $\left(11.0 \times 10^{9} / \mathrm{L}\right)$. His glucose, cholesterol, urea, and creatinine concentrations were all within normal range. His total bilirubin was moderately elevated $(32.4 \mu \mathrm{mol} / \mathrm{L})$, and his transaminase level was normal. He had a significantly high level of C-reactive protein $(55.8 \mathrm{mg} / \mathrm{L})$. His urine was clear. No serology or microbiology was performed. Due to the urgency of the case, no additional diagnostic evaluation (radiography, duplex scan, angiography, or neurography) was performed. Hemodynamic resuscitation was initiated immediately. Two large-bore intravenous catheters (16gauge) were inserted. Crystalloids and colloids were administered rapidly, and red blood cells and fresh frozen plasma (FFP) were ordered. Induction agents etomidate $(0.3 \mathrm{mg} / \mathrm{kg})$, fentanyl $(3 \mu \mathrm{g} / \mathrm{kg})$, and rocuronium $(1.2 \mathrm{mg} / \mathrm{kg})$ were administered. The patient was intubated and escorted to the operating room. Anesthesia was maintained with sevoflurane (0.7-1.3 minimum alveolar concentration), atracurium, and fentanyl. To achieve hemodynamic stability, vasopressors (dopamine 5-7 $\mu \mathrm{g} /$ minute) were used until several units of red blood cells and FFP were brought from the transfusion desk. To minimize the possibility of rebleeding, permissive hypotensive resuscitation was maintained.

At the operating table, we found large lacero-contusive and avulsive wounds with parts of biceps and brachialis muscle, fascia, and subcutaneous tissue completely torn from the humerus. After careful debridement, we approached the medial neurovascular bundle of arm, where we found complete laceration of the brachial artery, brachial and basilic vein and intact deep brachial artery, ulnar nerve, brachial nerve, and antebrachial cutaneus nerve (Fig. 2). We dissected these structures and obtained proximal and distal control. Due to extensive laceration of the brachial artery, it was not possible to perform end-to-end anastomosis. This was not the case with the brachial vein, which we were able to mobilize, debride, and reconstruct by end-to-end anastomosis. To reconstruct the brachial artery we used a 10-cm segment of saphenous vein harvested from the leg and implanted it between two ends of the debrided brachial artery (Fig. 3). The lacerated basilic vein was ligated. Afterwards, the muscles were sewn. Finally, a suction drain was placed. One week after surgery, following formation of granulating tissue, autologous skin graft was used to close the wound. 


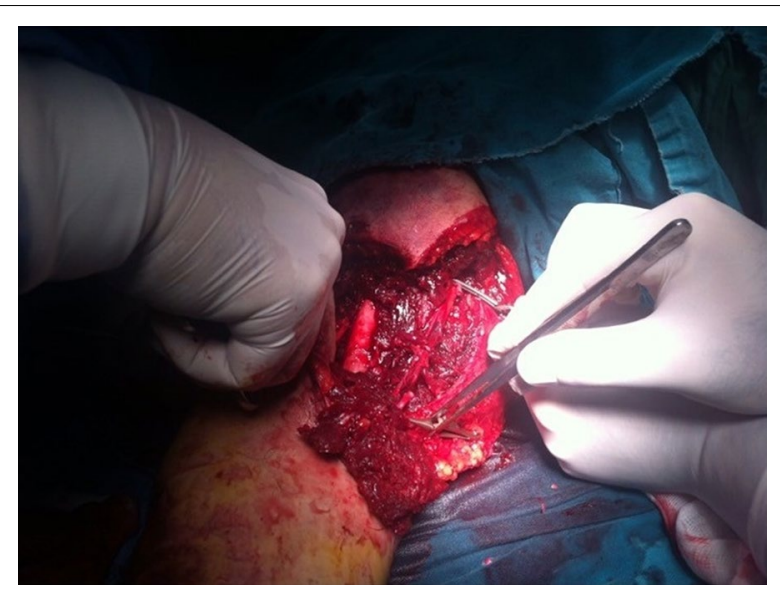

Fig. 2. Injured and clamped blood vessels of the arm, brachial artery, and brachial vein

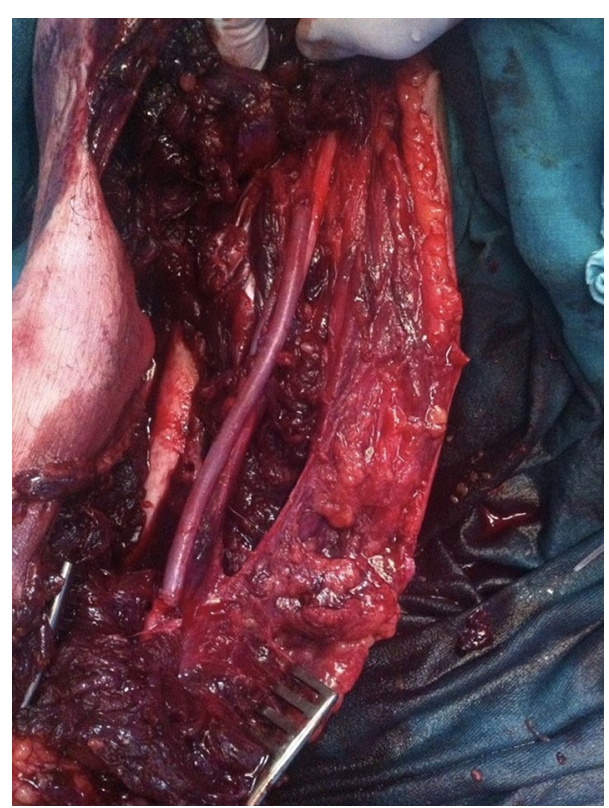

Fig. 3. Brachial artery reconstructed with autologous saphenous vein

After surgery, patient resuscitation continued. The patient was put on a broad spectrum of intravenous antibiotics (vancomycin and metronidazol), and antitetanus and antirabies prophylaxes. Enterococcus was isolated from the wound. The bacteria resulted sensitive to the mentioned antibiotics, thus we continued with the same treatment. The local infection was treated with frequent debridements. However, major blood loss and hemorrhagic shock caused by laceration of the brachial artery, brachial and basilic vein, infection, limb ischemia, and massive destruction of soft tissue of arm and forearm led to complicated postoperative course and caused renal failure. Therefore, the patient underwent several sessions of hemodialysis. Once the treatment was completed, the renal function, as well as the local and general condition of the patient, improved significantly.

The patient was discharged 3 weeks after the surgery. Follow-up clinical examination, electoneurography, and electromyogaphy of arm muscles (performed 6 months, 1 year, and 5 years after discharge) showed no signs of sensory or motor deficit (Fig. 4a, b).

\section{Discussion}

The majority of injuries in horse-related accidents occur when a person is blown or kicked by a horse, falls from a horse, gets struck by an object while riding a horse, gets trapped by a horse falling on them, and/or becomes entangled by reins $[4,5]$. Only $3-4.5 \%$ of these injuries are related to bites [6]. However, although rarely, horses are the animals most commonly involved in bite-related fatalities [2] and are responsible for almost $2 \%$ of all emergency admissions [1].

Because of the great deal of force exerted by an equine in closing its jaws, the severity of injuries may range from mild superficial pressure trauma, cutaneous breaks of the skin, deep lacerations with loss of tissue, and injuries to blood vessels and nerves, to amputations of digits or breast, and fractures [7-9]. These wounds are generally contaminated due to the large number of bacteria in the mouth of horse, and their treatment is difficult. Horse bites most commonly lead to infections with Burkholderia, Streptococcus, Staphylococcus, Rhodococcus, Actinobacillus, Yersinia, Pasteurella, Escherichia, Neisseria, Prevotella, Pseudomonas, Listeria, and Hendra and

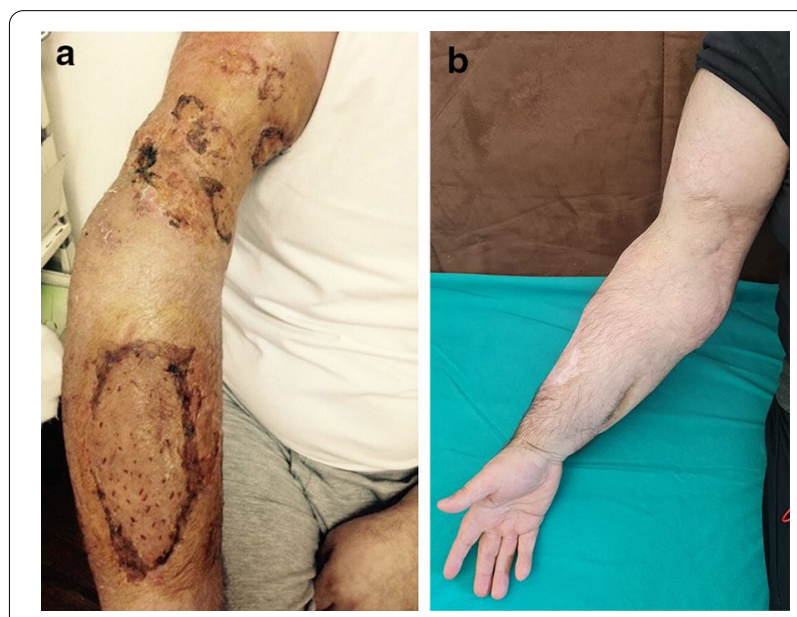

Fig. 4. Hand 6 weeks after injury (a) and 2 years after operation (b) 
Vesicular stomatitis virus species [10-12]. The wound in our patient was infected with Enterococcus.

Among horse-related injuries, fractures have been reported mainly following falling accidents [1]. Peel et al. [13] reported a case of fracture of the forearm bones following a horse bite that was treated with open reduction and internal fixation primarily. The patient sustained repeated infections with purulent wound discharge, from which mixed cultures of bacteria, including Staphylococcus aureus, Prevotella melaninogenica, Escherichia coli, and Pasteurella multocida, were isolated. More than 3 months after the initial attack by the horse, Actinobacillus suis was isolated by bone biopsy specimen.

The occurrence of bacterial infection after animal bites depends on several factors, such as the species of the animal aggressor (humans being associated with a higher risk of infection), the type and site of the injuries (wounds located on the hands have a higher infection risk), the care given to the wound, and factors inherent to the individual (greater risk in elderly, those with diabetes mellitus, vascular disease, etc). In relation to the type of wound, puncture wounds have been reported to have a higher infection rate after animal bites, possibly due to the deposition of bacteria deep into the skin [14]. There is evidence that use of prophylactic antibiotics after horse bites reduces infection $[5,15,16]$.

The presented case constitutes a clear example of both high severity of injury and postoperative complications. The horse bite caused laceration of the brachial artery, and the brachial and basilic vein, consequently leading to major blood loss and hemorrhagic shock. Limb ischemia, massive destruction of soft tissue of arm and forearm, and infection in postoperative period, accompanied by prior hemorrhagic shock, led to renal failure and hemodialysis. Both occurrences were identified as limb- and life-threatening to the patient.

The treatment of the patient included the use of autologous vein graft for vascular reconstruction and thorough care for the injured wound, with frequent debridement and necrectomies. Together with intravenous antibiotics and several hemodialysis sessions, the treatment led to patient recovery. Furthermore, reconstructive plastic surgery helped the appearance of the arm to return to a near-normal state.

\section{Conclusions}

Horse bites may cause severe injury to soft tissues and bones due to the strong force applied in the closing jaws of horses. The severity of these injuries can also be aggravated by the heavy load of different pathogenic bacteria in the secretion from the mouth of the horse and extensive destruction of soft tissues and ischemia. In certain cases, the combination of these negative factors can lead to severe infection and sepsis, therefore resulting in failure of kidney and other organs.

To prevent these complications, treatment of horse bite injuries requires extensive debridement of the wound, prompt revascularization, and broad-spectrum intravenous antibiotics. Prophylaxis against tetanus and rabies should also be provided. Only after the local and general condition of the patient become stable should plastic reconstructive surgery be provided. In case of extensive tissue loss and sepsis, hemodialysis may be required.

The composition of the team of physicians needed for treatment varies depending on the degree of injury as well as eventual complications. In the presented case, emergency department physicians, vascular and plastic surgeons, intensive care specialists, nephrologists, and infective care specialists were involved. In different instances, inclusion of other specialists may be necessary to save and functionalize the limbs of the patient, or save his/her life.

\section{Acknowledgements \\ Not applicable.}

\section{Authors' contributions}

$H R, L J$, and AK performed the surgery and analyzed and interpreted the data. $L J$ and $L V$ reviewed the literature. All authors were major contributors to the manuscript. All authors read and approved the final manuscript.

\section{Funding}

Not applicable.

\section{Availability of data and materials}

The data are available under consideration of the corresponding author on reasonable request.

\section{Declarations}

Ethics approval and consent to participate

This study was approved by the Ethical Committee of the University Clinical Center of Kosovo.

\section{Consent for publication}

Written informed consent was obtained from the patient for publication of this case report and any accompanying images. A copy of the written consent is available for review by the Editor-in-Chief of this journal.

\section{Competing interests}

The authors declare that they have no competing interests.

Received: 20 January 2021 Accepted: 15 April 2021

Published online: 25 May 2021

References

1. Dendle C, Looke D. Animal bites: an update for management with a focus on infections. Emerg Med Australas. 2008;20(6):458-67.

2. Lathrop SL. Animal-caused fatalities in New Mexico, 1993-2004. Wilderness Environ Med. 2007;18(4):288-92.

3. Köse R, Sögüt Ö, Mordeniz C. Management of horse and donkey bite wounds: a series of 24 cases. Plast Reconstr Surg. 2010;125(6):251e-e252.

4. Abu-Zidan FM, Rao S. Factors affecting the severity of horse-related injuries. Injury. 2003;34(12):897-900. 
5. Emet M, Beyhun NE, Kosan Z, Aslan S, Uzkeser M, Cakir ZG. Animal-related injuries: epidemiological and meteorogical features. Ann Agric Environ Med. 2009;16(1):87-92.

6. Fox SE, Ridgway EB, Slavin SA, Upton I III, Lee BT. Equestrian-related injuries: implications for treatment in plastic surgery. Plast Reconstr Surg. 2008;122(3):826-32.

7. Shipkov CD. Nasal amputation due to donkey bite: immediate and late reconstruction with a forehead flap. Injury Extra. 2004;35(11):85-90.

8. Abuzayed B, Aydin S, Bozkus S, Keles E, Karaaslan E, Sarioglu AC. Traumatic carotid artery dissection and bilateral vertebral artery occlusion after a horse attack: an unusual combination and etiology. J Neurol Surg Part A Central Eur Neurosurg. 2012;73(1):53-5.

9. Ho Quoc C, Meruta A, La Marca S, Fabiano L, Toussoun G, Delay E. Breast amputation correction of a horse bite using the lipomodeling technique. Aesth Surg J. 2013;33(1):93-6.

10. Bailey GD, Moore LV, Love DN, Johnson JL. Bacteroides heparinolyticus: deoxyribonucleic acid relatedness of strains from the oral cavity and oralassociated disease conditions of horses, cats, and humans. Int J Syst Evol Microbiol. 1988;38(1):42-4.
11. Langley R, Morris T. That horse bit me: zoonotic infections of equines to consider after exposure through the bite or the oral/nasal secretions. J Agromed. 2009;14(3):370-81.

12. Narsana N, Farhat F. Septic shock due to Pasteurella multocida bacteremia: a case report. J Med Case Rep. 2015;9(1):1-3.

13. Peel MM, Hornidge KA, Luppino M, Stacpoole AM, Weaver RE. Actinobacillus spp. and related bacteria in infected wounds of humans bitten by horses and sheep. J Clin Microbiol. 1991;29(11):2535-8.

14. Abrahamian FM, Goldstein EJ. Microbiology of animal bite wound infections. Clin Microbiol Rev. 2011;24(2):231-46.

15. Rothe K, Tsokos M, Handrick W. Animal and human bite wounds. Dtsch Arztebl Int. 2015;112(25):433.

16. Henton J, Jain A. Cochrane corner: antibiotic prophylaxis for mammalian bites (intervention review). J Hand Surg (Eur Volume). 2012;37(8):804-6.

\section{Publisher's Note}

Springer Nature remains neutral with regard to jurisdictional claims in published maps and institutional affiliations.
Ready to submit your research? Choose BMC and benefit from:

- fast, convenient online submission

- thorough peer review by experienced researchers in your field

- rapid publication on acceptance

- support for research data, including large and complex data types

- gold Open Access which fosters wider collaboration and increased citations

- maximum visibility for your research: over $100 \mathrm{M}$ website views per year

At BMC, research is always in progress.

Learn more biomedcentral.com/submissions 